\title{
Low biomass microbiota in the upper genital tract of reproductive age women: fact or fiction?
}

\author{
Thor Haahr ${ }^{1,2^{*}} \mathbb{0}$, Jørgen Skov Jensen ${ }^{3}$, Signe Altmäe $e^{4,5,6}$ and Peter Humaidan ${ }^{1,2}$
}

Dear Sir,

We read with interest the recent publication by Wei et al. [1], investigating the microbiome of the reproductive tract in regular cycling women $(\mathrm{N}=50)$, who underwent laparoscopic surgery for benign gynecological tumors. The study is in fact a re-analysis of a prior study [2], using a case control design to compare the microbiome of various anatomical sites along the reproductive tract; $16 \mathrm{~S}$ rRNA gene sequencing was performed in women with verified endometriosis (staging as defined by American Fertility Association) versus controls with no endometriosis. The authors conclude that endometriosis patients have an altered endometrial and peritoneal fluid microbiota containing "signature species" as compared to non-endometriosis controls. However, before the abovementioned conclusion can be drawn, we aim to highlight important limitations which are key elements of good practice generally relevant to low biomass microbiota studies.

First, transparency and replicability are key issuesalso in microbiome research [3]. Thus, the authors should be encouraged to make available the specifics of the data analysis, including the bioinformatic pipeline from raw sequences to species annotation, and also to clarify how figures were constructed. As a matter of fact, it seems that Fig. 1 only shows genus annotation and in Fig. 2 only one bacterium-Lactobacillus iners-is identified to the species level. Metadata is also lacking about the cases and controls.

\footnotetext{
*Correspondence: thohaa@rm.dk

1 Department of Clinical Medicine, Aarhus University, Aarhus, Denmark

Full list of author information is available at the end of the article
}

Second, it is important to make available results from negative controls at all major steps through analysis. This would increase the confidence in the low abundant microbiota results being a true biological signal and not a false positive signal-e.g. from contamination. Thus, Wei et al. ought to provide microbiome results on the negative controls, e.g. a comparison in terms of sequencing depth and "signature OTUs" in the negative controls compared to samples from especially the low bio-mass sites such as the endometrium and the peritoneal fluid. In fact, more than $50 \%$ of the "signature OTUs" in Fig. 2 of the endometrial and peritoneal fluid, respectively, are well-known contaminants from sequenced blank controls $[4,5]$.

Third, when choosing to report new diagnostic/stratification methods, it is important to clearly state what defines them. Wei et al. stratified samples according to the dominant genus. What was the rationale behind this method? As previously mentioned, no information exists in the publication on taxon annotation. Furthermore, there is no definition as to what determines "a dominant genus"; lastly why did the authors choose seven subtypes?

Despite the somewhat unclear nature of these seven subtypes, the authors further elaborate their analysis to report the ratio between those arbitrary seven subtypes as evidence for differences between endometriosis cases and controls. Instead, we would suggest that the authors applied a rigorous analysis, utilizing the raw sequencing data, to compare alpha and beta diversity metrics etc. between endometriosis cases and controls. In their first publication [2], interesting data was reported from qPCR analyses on the total abundance of Lactobacilli ascending from the vagina to the upper reproductive tract. That information would have been interesting also in the present publication. Finally, it has been shown that ascending infection is increased in patients with bacterial

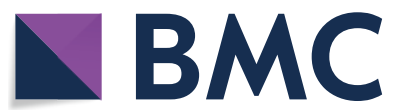

(c) The Author(s) 2020. This article is licensed under a Creative Commons Attribution 4.0 International License, which permits use, sharing, adaptation, distribution and reproduction in any medium or format, as long as you give appropriate credit to the original author(s) and the source, provide a link to the Creative Commons licence, and indicate if changes were made. The images or other third party material in this article are included in the article's Creative Commons licence, unless indicated otherwise in a credit line to the material. If material is not included in the article's Creative Commons licence and your intended use is not permitted by statutory regulation or exceeds the permitted use, you will need to obtain permission directly from the copyright holder. To view a copy of this licence, visit http://creativeco mmons.org/licenses/by/4.0/. The Creative Commons Public Domain Dedication waiver (http://creativecommons.org/publicdomain/ zero/1.0/) applies to the data made available in this article, unless otherwise stated in a credit line to the data. 
vaginosis, OR 5.7 (95\% CI, 1.8-18.3) [6]-could authors provide information on bacterial vaginosis status?

In summary-and in contrast to the importance statement made by the authors - we find that the data analysis itself as well as the information level regarding the data analysis in the publication are not sufficient to answer the question whether a real microbiota of the upper genital tract exists and whether it is associated with endometriosis. In our view and taking the current methods description into consideration, the conclusion of the study could also have been that upper genital tract samples were dominated by well-known contaminants which caused the observed difference between endometriosis cases and controls.

\section{Acknowledgements}

Not applicable.

\section{Authors' contributions}

TH drafted the manuscript. PH, JSJ and SA revised the manuscript. All authors read and approved the final manuscript.

\section{Funding}

Not applicable.

\section{Availability of data and materials}

Not applicable.

\section{Ethics approval and consent to participate}

Not applicable.

\section{Consent for publication}

All authors have read and approved this manuscript for publication.

\section{Competing interests}

TH has received honoraria for lectures from Ferring, IBSA, Besins and Merck. PH received unrestricted research grants from MSD, Merck, and Ferring as well as honoraria for lectures from MSD, Merck, Gedeon-Richter, Theramex, and IBSA. JSJ has received speaker's fee from Hologic, BD, SpeeDx, and Cepheid and serves scientific advisory board of Roche Molecular Systems, Abbott Molecular, and Cepheid. PH, TH and JSJ received an unrestricted research grant from Osel inc. which produces LACTIN-V, a live biotherapeutic product with Lactobacillus crispatus. PH and TH are listed as inventors in an international patent application (PCT/US2018/040882) involving "Use of vaginal lactobacilli for improving the success rate of in vitro fertilization". SA reports funding and salary from The Spanish Ministry of Economy, Industry and Competitiveness (MINECO) and European Regional Development Fund (FEDER): grants RYC-2016-21199 and ENDORE SAF2017-87526-R; FEDER/Junta de AndalucíaConsejería de Economía y Conocimiento: MENDO (B-CTS-500-UGR18).

\section{Author details}

${ }^{1}$ Department of Clinical Medicine, Aarhus University, Aarhus, Denmark. ${ }^{2}$ The Fertility Clinic Skive, Skive Regional Hospital, Resenvej 25, 7800 Skive, Denmark. ${ }^{3}$ Statens Serum Institut, Microbiology and Infection Control, Copenhagen, Denmark. ${ }^{4}$ Department of Biochemistry and Molecular Biology, Faculty of Sciences, University of Granada, 18071 Granada, Spain. ${ }^{5}$ Instituto de Investigación Biosanitaria ibs.GRANADA, 18014 Granada, Spain. ${ }^{6}$ Competence Centre on Health Technologies, 50410 Tartu, Estonia.

Received: 10 June 2020 Accepted: 27 August 2020

Published online: 09 September 2020

\section{References}

1. Wei W, Zhang X, Tang H, Zeng L, Wu R. Microbiota composition and distribution along the female reproductive tract of women with endometriosis. Ann Clin Microbiol Antimicrob. 2020;19(1):15.

2. Chen C, Song X, Wei W, Zhong H, Dai J, Lan Z, et al. The microbiota continuum along the female reproductive tract and its relation to uterinerelated diseases. Nat Commun. 2017;8(1):875.

3. Haahr T, Humaidan P, Jensen JS. Non-transparent and insufficient descriptions of non-validated microbiome methods and related reproductive outcome results should be interpreted with caution. Hum Reprod. 2019;34:2083-4.

4. Salter SJ, Cox MJ, Turek EM, Calus ST, Cookson WO, Moffatt MF, et al. Reagent and laboratory contamination can critically impact sequence-based microbiome analyses. BMC Biol. 2014;12(12):87.

5. Eisenhofer R, Minich JJ, Marotz C, Cooper A, Knight R, Weyrich LS. Contamination in low microbial biomass microbiome studies: issues and recommendations. Trends Microbiol. 2019;27(2):105-17.

6. Swidsinski A, Verstraelen H, Loening-Baucke V, Swidsinski S, Mendling W, Halwani Z. Presence of a polymicrobial endometrial biofilm in patients with bacterial vaginosis. PLoS ONE. 2013;8(1):e53997.

\section{Publisher's Note}

Springer Nature remains neutral with regard to jurisdictional claims in published maps and institutional affiliations.

Ready to submit your research? Choose BMC and benefit from:

- fast, convenient online submission

- thorough peer review by experienced researchers in your field

- rapid publication on acceptance

- support for research data, including large and complex data types

- gold Open Access which fosters wider collaboration and increased citations

- maximum visibility for your research: over 100M website views per year

At BMC, research is always in progress.

Learn more biomedcentral.com/submissions 